\title{
Esterification of By-products of Biodiesel Fuel Production with Methanol and Technical Glycerol Using Biocatalysts
}

\author{
Milda Gumbytė, Violeta Makarevičienė and Eglė Sendžikienė \\ Lithuanian University of Agriculture, Institute of the Environment, Lithuania
}

(received in May, 2011, accepted in June, 2011)

\begin{abstract}
In production of biodiesel fuel several by-products, such as glycerol and free fatty acids, are formed. The options for applying biochemical methods to process these by-products have been studied. The process of free fatty acid esterification with methanol using Lipozyme RM IM is to be performed in steps, with gradual addition of methanol into the reaction media. In 4 hours of a multi-step process it is possible to esterify up to $60 \%$ of free fatty acids. Novozym 435 is not inactivated by methanol, therefore, esterification with methanol of free fatty acids can be performed in one step. Free fatty acid esterification with glycerol is slowed down by admixtures present in by-products of biodiesel fuel production. After 7 hours of reaction, only $82.2 \%$ of free fatty acids react when using Novozym 435 , and only $41.7 \%$ do in a case of Lipozyme RM IM, whereas in the case of esterification of pure oleic acid with pure glycerol the amounts reach $97.7 \%$ and $84.8 \%$, respectively. Efficiency of ferment preparation Novozym 435 is almost twice higher compared to Lipozyme RM IM. However, taking into account the prices of ferment preparations, it is possible to conclude that Lipozyme RM IM has future prospects in industrial synthesis.
\end{abstract}

Key words: esterification, methanol, glycerol, free fatty acids, lipases, biodiesel fuel.

\section{Introduction}

The interest in alternative energy sources has been continuously growing, as humankind is becoming increasingly dependent on crude oil and fossil fuel (Akoh et al. 2007). Because the stock of crude oil has been decreasing, vegetable oils have attracted attention as potential sources of renewable energy (Kumari et al. 2009). However, the biofuels obtained from those sources, viz biodiesel fuels, still have rather high production costs and are very slowly finding their place on the market. This slowness is due to inability of these biofuels to compete with fossil fuels in terms of costs, unless they are subsidized by the state. In the EU countries, production of biodiesel fuel is most commonly performed via esterification of rapeseed oil with methanol using sodium or potassium hydroxide (or sodium or potassium methylate) as a catalyst. While chemical catalysis is attractive because of its speed and high output of methyl esters, it also has some drawbacks. One of them is that when chemical catalysis is used in production of raw materials containing a high content of free fatty acids, soaps acting as emulsifiers are formed. It becomes difficult to separate glycerol formed during the transesterification reaction, and subsequently the production of high quality biodiesel fuel that conforms to the requirements of standard EN 14214 is hampered. Therefore, among scienists there is a great interest in development of biotechnological methods to produce biodiesel fuel. In this study, the ferment preparation lipases that catalyze fat hydrolysis, esterification of free fatty acids, and transesterification of triglycerides have been used as catalysts. Application of biotechnological methods to production of biodiesel fuel has several advantages: it may take place under milder conditions (lower temperatures, lower pressure and $\mathrm{pH}$ ); it contributes less pollution to the environment (Deng et al. 2003); it allows for the control of the progress of reaction and increases the production yield (Mat Radzi et al. 2005).

Biocatalysts are compounds of albuminous origin and can accelerate chemical reaction rates by thousands-folds. For esterification and transesterification reactions, lipases (ferments of 
hydrolase class EC 3.1.1.3) are used as catalysts to catalyze the reactions during which hydrolasic decomposition takes place inside of molecules. Apart from this role, a physiological function of ferments is to regulate the circulation of lipids. Lipases can be classified either as strict (when they are selective for a particular substrate structure), or not strict (when they can be used in the hydrolysis reactions of different substrates or in different synthesis reactions). Despite their similar functions as catalysts, lipases of different origins greatly differ in their physical and chemical properties (Goddard et al. 2000; Yang eta 1. 2005).

In the production of biodiesel fuel several byproducts, such as glycerol and free fatty acids, are formed. Effective utilization of these by-products has a potential to increase biofuel production profitability (Gumbyte and Makareviciene 2007, Montrimaite et al. 2010). Free fatty acids are also formed in the process of vegetable oil refining; however, the demand for vegetable oil is not great, and thus, their price is relatively low. Free fatty acids can be successfully used in production of biodiesel fuel by esterifying them to the same fatty acid methyl esters. These esters are obtained during transesterification of vegetable oil (i.e., when producing biodiesel fuel). The use of biocatalysts is particularly attractive, allowing both esterification and transesterification reactions to be performed at the same time. In contrast, in chemical catalysis esterification of free fatty acids must be performed in a separate step because it is catalyzed by acids, while transesterification requires the use of alkalis (Ergan et al. 2004; Makareviciene and Gumbyte 2008).

With an increase in biodiesel fuel production volumes, glycerol utilization becomes a problem. Glycerol is formed during a transesterification reaction of triglycerides with methanol and it is separated from biodiesel fuel as by-product. On average, about $7 \%$ of technical glycerol is formed from biodiesel fuel produced. This glycerol (approximately of $85 \%$ purity, depending on the applied production technology) could be purified up to $99.8 \%$ and used in different industries: paper, ester, poly-glycerol ester, tobacco, cellulose, food, beverage, alkyl resin and other branches of industry (Gumbyte and Makareviciene 2007; Makareviciene and Gumbyte 2008; Triphati et al. 2006). However, refining of glycerol is a rather expensive process, and the supply of glycerol exceeds the market demand. Therefore, it is difficult for biodiesel fuel producers to sell it at profitable prices. Glycerol, like free fatty acids, can be processed by applying biotechnological methods. Through these methods, useful products such as mono- and diglycerides can be obtained, which can be used as emulsifiers and stabilizers in different industries: food, pharmaceuticals, plastics, and lubricants. (Yang et al. 2005; Kowalski et al. 2004; Royon et al. 2007).

Essentially, production of mono- and diglycerides from glycerol is an analogous process to esterification of free fatty acids, in which the same free fatty acids formed during biodiesel fuel production can be utilized. This process can be performed using the same lipases, and efficient processing of both by-products of biodiesel fuel production would allow a reduction in the costs of biodiesel fuel production and allow an increase in profitability of their production (Gumbyte and Makareviciene 2007; Royon et al. 2007; Warabi et al. 2004).

The aim of our work was to investigate possibilities of using lipases as catalysts in processing by-products of biodiesel fuel production (free fatty acids and glycerol).

\section{Materials and methods}

The following materials were used for the study of glycerolysis and methanolysis processes:

- Oleic acid (analytical grade, Ekros, Russia),

- Free fatty acids (JSC "Rapsoila", Lithuania);

- Glycerol (analytical grade, Penta, Czech Republic),

- Technical glycerol (Mestila, Lithuania);

- Methanol (analytical grade, Lachner, Czech Republic),

- $\quad 0.1 \mathrm{~N} \mathrm{KOH}$ (fixanals, Reachim, Russia),

- Ethanol ( $>96 \%$, SC "Stumbras", Lithuania),

- Diethyl ether (analytical grade, Lachema, Czech Republic).

The following lipases were used as biocatalysts for glycerolysis and methanolysis:

- Novozym 435 (lipase from Candida antarctica, immobilised on polypropylene, activity - 10 PLU/mg, from Novo Nordisk (Denmark));

- Lipozyme RM IM (lipase from Rhizomucor miehei, immobilised on macro porous plastic, activity - 150 IUN/g, from Novo Nordisk (Denmark));

- Lipozyme TL IM (lipase from Thermomyces lanuginosa, immobilised on silica gel, activity 250 IUN/g, from Novo Nordisk (Denmark));

- Lipase F-EC (lipase from Rhizopus oryzae, immobilised on dextrin, activity $-150 \mathrm{U} / \mathrm{mg}$, from Musster (Germany));

- Lipase G “Amano"50 (lipase from Penicillium camembertii, activity - $50 \mathrm{U} / \mathrm{mg}$, from Musster (Germany)).

In this study, the following methods were used:

Eterification reaction was performed in a thermo-stated flask mixed at a constant mixing speed $\left(\approx 600 \mathrm{~min}^{-1}\right.$ ) on a magnetic mixer (IKA RCT basic) and the temperature $\left(40^{\circ} \mathrm{C}\right.$ or $\left.70^{\circ} \mathrm{C}\right)$.

Formation of the products was determined by a decrease in acidity of the reaction media. Acidity analysis was performed following standard EN ISO 660:2009 Animal and vegetable fats and oils. Determination of acid value and acidity.

For the study of glycerolysis processes, thin layer chromatography was used. 


\section{Results and discussions}

In order to select the most efficient biocatalyst (lipase) for esterification of free fatty acids with methanol and glycerol, catalytic efficiency of lipases listed in the section "Materials and Methods" was assessed. In the initial stage, the study was performed using pure reagents - analytical grade oleic acid, glycerol and methanol. Esterification with methanol was performed by using each lipase under the same conditions: reaction temperature $\left(40^{\circ} \mathrm{C}\right)$, initial molar ratio of oleic acid and methanol $(0.5: 1)$ amount of lipases $(3 \%$ of the mass of oleic acid). Esterification with glycerol was performed at the same reaction temperature $\left(50^{\circ} \mathrm{C}\right)$, with the same initial molar ratio of oleic acid and methanol (1:1) and the same amount of lipases ( $3 \%$ of the mass of oleic acid). The progress of the reaction was assessed according to the decrease in oleic acid concentration in the reaction media.

The obtained data show that in both processes of esterification ferment preparations Novozym 435 and Lipozyme RM IM are of the highest efficiency (Table 1). The other examined catalysts have not shown any significant efficiency in the methanolysis process.
The esterification reaction with methanol using Novozym 435 preparation was the most intensive during the first hour, during which almost all of methanol present in the reaction media reacted $(47 \%$ of oleic acid from possible $50 \%$, based on the ratio of methanol and oleic acid used for the reaction). In esterification with glycerol using lipase Novozym $435,20 \%$ of oleic acid had reacted after only one hour of reaction. Lipozyme RM IM was less effective as a catalyst. After one hour of reaction only approximately $5 \%$ of oleic acid had reacted when Lipozyme RM IM was used. However, after two hours, effectiveness of the preparations became similar. In both cases, $60 \%$ of oleic acid reacted. When esterification with glycerol was carried on for seven hours and lipases were characterized on the basis of their highest efficiencies, over $80 \%$ of oleic acid reacted. Therefore, for the further study of esterification with methanol and glycerol processes, lipases Novozym 435 and Lipozyme RM IM characterized by their higher activities were selected.

Table 1 .

Acidity of the reaction mixture during esterification with methanol and glycerol

\begin{tabular}{|c|c|c|c|c|c|c|c|c|c|c|}
\hline \multirow{3}{*}{$\underset{\text { hime, }}{\text { Time }}$} & \multicolumn{10}{|c|}{ Acidity, \% } \\
\hline & \multicolumn{5}{|c|}{ Esterification with glycerol } & \multicolumn{5}{|c|}{ Esterification with methanol } \\
\hline & $\begin{array}{c}\text { Novozym } \\
435 \\
\end{array}$ & $\begin{array}{c}\text { Lipoz-yme } \\
\text { RM IM }\end{array}$ & $\begin{array}{c}\text { Lipoz-yme } \\
\text { TL IM }\end{array}$ & $\begin{array}{c}\text { Lipase F- } \\
\text { EC }\end{array}$ & Lipase $\mathrm{G}$ & $\begin{array}{c}\text { Novozy } \\
\text { m 435 }\end{array}$ & $\begin{array}{c}\text { Lipoz-yme } \\
\text { RM IM }\end{array}$ & \begin{tabular}{c|} 
Lipoz-yme \\
TL IM
\end{tabular} & $\begin{array}{c}\text { Lipase F- } \\
\text { EC }\end{array}$ & Lipase $\mathrm{G}$ \\
\hline 0 & 74.85 & 74.82 & 74.70 & 74.60 & 74.85 & 110.05 & 110.48 & 111.22 & 110.42 & 110.03 \\
\hline 1 & 69.87 & 66.91 & 74.70 & 74.60 & 69.94 & 54.00 & 57.26 & 89.68 & 91.50 & 93.13 \\
\hline 2 & 45.39 & 49.78 & 74.69 & 74.60 & 66.96 & 52.59 & 52.76 & 81.29 & 90.42 & 92.64 \\
\hline 3 & 29.83 & 35.96 & 74.69 & 74.60 & 64.19 & 51.89 & 52.21 & 79.37 & 90.16 & 92.21 \\
\hline 4 & 24.05 & 28.77 & 74.69 & 74.60 & 57.07 & 51.80 & 52.18 & 77.45 & 90.05 & 92.2 \\
\hline 5 & 20.71 & 25.52 & 74.69 & 74.59 & 55.05 & 51.71 & 52.13 & 76.28 & 89.90 & 92.18 \\
\hline 6 & 17.56 & 20.46 & 74.68 & 74.58 & 52.48 & 51.68 & 52.09 & 76.05 & 89.80 & 92.15 \\
\hline 7 & 15.52 & 17.17 & 74.68 & 74.58 & 50.81 & 51.50 & 52.05 & 76.00 & 89.70 & 92.14 \\
\hline
\end{tabular}

In order to establish optimal conditions for ferment preparations in esterification processes, the influence of the ferment amount, the temperature and duration of the reaction on effectiveness of esterification have been assessed. Our previous results have shown that the optimal temperature for oleic acid esterification with methanol and glycerol when using lipases Novozym 435 and Lipozyme RM IM is $40^{\circ} \mathrm{C}$ and $70^{\circ} \mathrm{C}$, respectively; the optimal amount of ferment preparation Novozym 435 is $3 \%$ of the oleic acid amount, and the optimal amount of Lipozyme RM IM preparation is $7 \%$ of the oleic acid amount (Gumbyte and Makareviciene 2007; Makareviciene and Gumbyte 2008). It has been observed that Lipozyme RM IM is inactivated by methanol. Therefore, the molar ratio of methanol and oleic acid in the reaction media should not exceed 0.5:1. Furthermore, in order to obtain a high yield of esters, it is necessary to perform the reaction in three steps. The optimal duration of this reaction is 1-2 hours, with gradual addition of the necessary amount of methanol (0.5 moles per one mole of oleic acid). Considering the fact that Lipozyme RM IM is 2-3 times cheaper than Novozym 435, its use is quite attractive (Makareviciene and Gumbyte 2008). When oleic acid is esterified with analytical grade glycerol, it is not necessary to perform the process in multiple steps. The optimal temperature of the process is higher and the latter can be performed at up to $70{ }^{\circ} \mathrm{C}$. The optimal amount of lipase is the same as in esterification with methanol, the process duration being four hours.

Because by-products - technical glycerol and free fatty acids formed in production of biodiesel fuel are not pure, it is necessary to evaluate whether it is possible to use them directly in the processes of esterification with methanol and glycerol (i.e. removing the need for purification of by-products and thus saving energy and material costs). For this purpose, it was necessary to assess the effect of admixtures present in non-purified products on the efficiencies of the esterification processes and 
compare them to pure materials. The composition of technical glycerol used in this study is given in Table 2 , and the composition of the free fatty acids is shown in Table 3.

Table 2.

Composition of technical glycerol

\begin{tabular}{|l|c|c|}
\hline \hline Index & Value & Analysis method \\
\hline Water, \% & 5.8 & EN ISO 12937 \\
\hline Glycerol, \% & 87.7 & ISO 2879 \\
\hline Soap, $\%$ & - & ISO 684 \\
\hline $\mathrm{Na}_{3} \mathrm{PO}_{4} \%$ & 4.3 & ISO 850 \\
\hline Methanol, \% & traces & ISO 1387 \\
\hline Free fatty acids, \% & 2.1 & EN ISO 660 \\
\hline
\end{tabular}

Table 3.

Composition of free fatty acids

\begin{tabular}{|l|c|c|}
\hline Index & Value & Analysis method \\
\hline Water, \% & 3.71 & EN ISO 8534 \\
\hline Glycerol, \% & 8.6 & ISO 2879 \\
\hline Soap, \% & 0.3 & ISO 684 \\
\hline Methanol, \% & 9.5 & EN ISO 14110 \\
\hline Free fatty acids, \% & 59.9 & EN ISO 660 \\
\hline $\begin{array}{l}\text { Fatty acids methyl } \\
\text { esters, \% }\end{array}$ & 17.7 & EN 14103 \\
\hline \hline
\end{tabular}

The process of esterification of free fatty acids with methanol was examined using the most efficient biocatalysts (Novozym 435 and Lipozyme RM IM). The reaction was performed at the reaction temperature of $40^{\circ} \mathrm{C}$, a molar ratio of free fatty acids to methanol being $1: 1.5$. The amount of catalyst was $3 \%$ (of the amount of free fatty acids) when Novozym 435 was used, and 7\% with Lipozyme RM IM. Considering the fact that Lipozyme RM IM is inactivated by methanol (Makarevičienè et al. 2008), a multi-step process was performed for the comparison. Results of the study are presented in Figure 1.

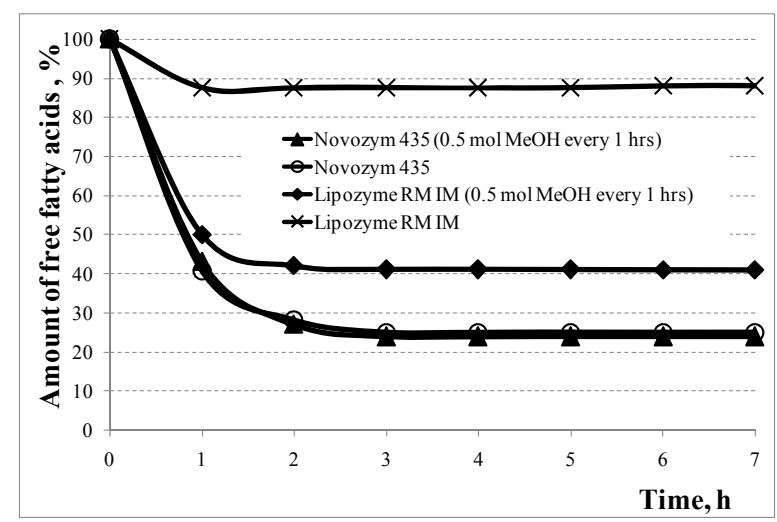

Fig. 1. Efficiency of lipases in esterification of free fatty acids with methanol

The data show that when using ferment preparation Novozym 435, similar results are obtained when the process is performed in three steps (adding 0.5 mole methanol per one mole of free fatty acids) and when it is performed in one step (using 1.5 mole of methanol per one mole of free fatty acids). When using Lipozyme RM IM, efficiency of the process is significantly higher when performing it in steps. When $3 \%$ of Novozym 435 was used, the reaction was the most intensive during the first hour, during which $59 \%$ of free fatty acids were reacted in both one-step and multi-step processes. After two hours, $28 \%$ of the free fatty acids remained nonreacted. When continuing the reaction for a longer period of time, the yield essentially did not change. Using Lipozyme RM IM in a one-step process, the reaction of only $12 \%$ of free fatty acids resulted after the first hour. During the following hours the yield did not change, it confirmed the fact that methanol inactivated the ferment, as we had established before (Makareviciene and Gumbyte 2008). In contrast, in the multi-step process $50 \%$ of free fatty acids had reacted during the first hour only. During the second hour of the reaction, after addition of 0.5 mole of methanol (per mole of free fatty acids), the reaction proceeded slowly though its mixture contained a sufficient amount of methanol. After three hours the reaction mixture still contained $41 \%$ of non-reacted free fatty acids.

In order to assess the possibility of using technical glycerol in esterification of free fatty acids, the study was carried out in two steps. In the first step, esterification with glycerol of pure oleic acid was examined, and in the second step esterification with glycerol of free fatty acids, i.e. a by-product of biodiesel fuel production, was studied. The reaction was performed at $70^{\circ} \mathrm{C}$, with a molar ratio of oleic acid (free fatty acids) to glycerol being 1:1 and 3\% of Novozym 435 and 7\% of Lipozyme RM IM (of the amount of free fatty acids). Results obtained by means of the thin-layer chromatography (TLC) analysis are presented in Figures 2 and 3, and results of comparative study of reaction media acidity are given in Table 4.

Results of the TLC analysis show that when analytical grade oleic acid is used (Fig. 2), effectiveness of the esterification process is much higher if compared to the use of free fatty acids (Fig. 3 ). In this case biocatalyst Novozym 435 is much more effective than Lipozyme RM IM.

Together with the TLC analyses, the concentration of oleic acid and free fatty acids in the reaction mixture was determined (taking samples every hour). The obtained results are presented in Table 4, where the results obtained using pure materials (analytical grade oleic acid and glycerol) for esterification with glycerol are also shown for comparison purposes.

The data show that when using free fatty acids and technical glycerol the efficiency of ferment preparations is lower than that when using analytical grade reagents - oleic acid and glycerol. For oleic acid esterification reaction, when pure glycerol is replaced by technical glycerol, the same results can be achieved in a longer period of time. For example, when using Novozym 435 and when acidity of the reaction mixture is the same as the initial one, the content of free fatty acids goes down to $3.91 \%$ in 4 hours when pure materials are used. 


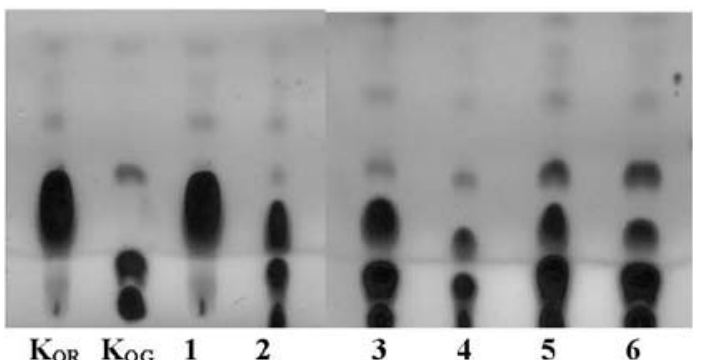

(a)

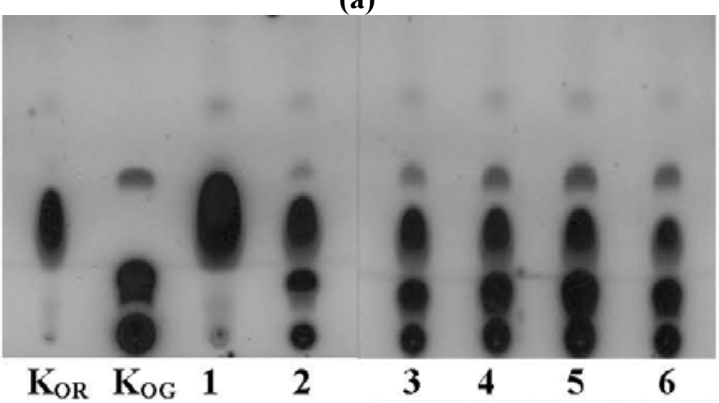

(b)

Fig. 2. Reaction of oleic acid esterification by technical glycerol, when: $a$-Novozym 435, b-Lipozyme RM $I M$ is used as a catalyst: $K_{O R}$ - control (oleic acid), $K_{O G}-$ control (glycerides mixture). Reaction duration: 1 - 0 hrs, 2-1 hrs, 3-2 hrs, 4 -3 hrs, $5-4$ hrs, 6-5 hrs.

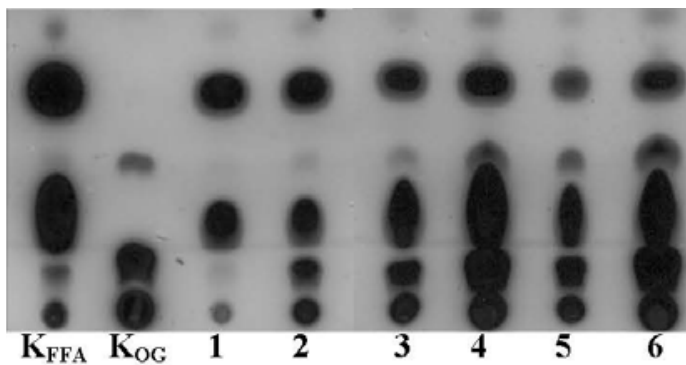

(a)

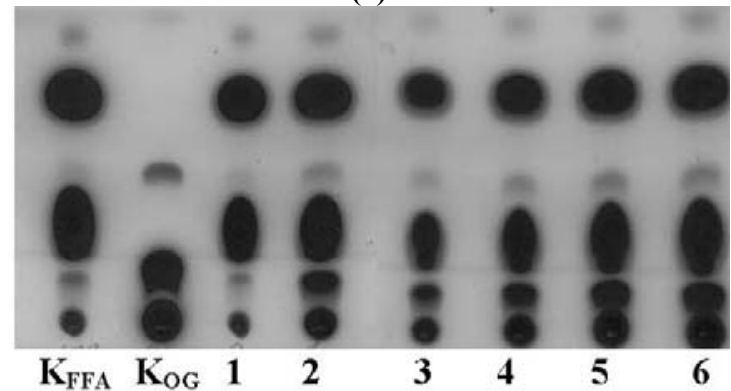

(b)

Fig. 3. Reaction of free fatty acids esterification by technical glycerol, when: a- Novozym 435, bLipozyme RM IM is used as a catalyst: $K_{F F A}-$ control (free fatty acids), $K_{O G}$ - control (mixture of glycerides). Reaction duration: $1-0$ hrs, $2-1$ hrs, 3-2 hrs, 4-3 hrs, 5-4 hrs, 6-5 hrs.

Table 4. Acidity of the reaction mixture applying esterification with glycerol

\begin{tabular}{|c|c|c|c|c|c|c|}
\hline \multirow{3}{*}{$\begin{array}{c}\text { Time, } \\
\text { hrs }\end{array}$} & \multicolumn{6}{|c|}{ Acidity, \% } \\
\hline & \multicolumn{2}{|c|}{ OR+G } & \multicolumn{2}{|c|}{ OR + TG } & \multicolumn{2}{|c|}{ FFA+ TG } \\
\hline & $\begin{array}{c}\text { Novozym } \\
435\end{array}$ & $\begin{array}{c}\text { Lipozyme RM } \\
\text { IM }\end{array}$ & $\begin{array}{c}\text { Novozym } \\
435\end{array}$ & $\begin{array}{c}\text { Lipozyme RM } \\
\text { IM }\end{array}$ & Novozym 435 & $\begin{array}{c}\text { Lipozyme RM } \\
\text { IM }\end{array}$ \\
\hline 0 & 74.47 & 73.70 & 72.27 & 72.52 & 22.25 & 22.57 \\
\hline 1 & 23.32 & 35.23 & 36.30 & 45.97 & 5.47 & $\begin{array}{ll}7.19 \\
\end{array}$ \\
\hline 2 & 13.71 & 21.13 & 26.12 & 30.95 & 5.20 & 16.54 \\
\hline 3 & 8.12 & 15.87 & 16.47 & 23.38 & 5.01 & 14.14 \\
\hline 4 & 3.91 & 14.23 & 10.33 & 21.65 & 4.85 & 13.73 \\
\hline 5 & 2.37 & 12.64 & 7.72 & 21.48 & 4.15 & 13.57 \\
\hline 6 & 1.90 & 12.02 & 5.24 & 21.25 & 4.03 & 13.36 \\
\hline 7 & 1.74 & 11.20 & 4.10 & 21.05 & 3.95 & 13.16 \\
\hline
\end{tabular}

However, when pure glycerol is replaced with technical glycerol, reaction mixture acidity of $4.1 \%$ can be achieved in 7 hours. The reaction is even more complicated when ferment preparation Lipozyme RM IM is used. When using technical glycerol for esterification of oleic acid, even after $7 \mathrm{hrs}$ of the process, acidity goes down only to $21.1 \%$. However, after 4 hours, the process, in principle, discontinues and no significant changes in acidity were observed even after increasing the duration further. Meanwhile, when using pure materials in the glycerolysis process, a continuous decrease in acidity was observed, and after 7 hours it reached $11.2 \%$.

These results show that when Novozym 435 is used as a catalyst in the reaction media where oleic acid and glycerol are of analytical grade, $97.7 \%$ of the oleic acid react in 7 hours. When pure glycerol is replaced with technical glycerol, only $94.3 \%$ is reacted in this time frame. When Lipozyme RM IM is used within the same period of time, $84.8 \%$ of the oleic acid react using pure reagents, compared only to $70.9 \%$ when technical glycerol is used. These observations can be explained by both different activity levels of the ferment preparations and the fact that technical glycerol contains only $87.7 \%$ of glycerol.

An even more complex reaction takes place between by-products of biodiesel fuel production: free fatty acids and technical glycerol (Table 4). In this case, ferment preparation Novozym 435 demonstrates better efficiency. When using this preparation, the maximum reaction rate has been observed during the first hour of the reaction when acidity dropped from $22.5 \%$ to $5.47 \%$. When the reaction is allowed to take 
place over a longer period of time, acidity continued to drop, but not significantly. However, after 5 hours, the rate of decline in acidity slowed down considerably, and after 7 hours it was $3.95 \%$. It is interesting to point out that during the first hour of the process, $75.4 \%$ of free fatty acids present in the media of reaction were reacted, and after 7 hours, this percentage increased up to $82.2 \%$. Using Lipozyme RM IM, the maximum change in acidity was observed when the reaction lasted up to 4 hours. During this period acidity decreased from $22.57 \%$ to $13.73 \%$ (in other words, $39.1 \%$ of free fatty acids reacted, whereas in 7 hours only $41.7 \%$ did).

After comparing esterificatrion results to those of the glycerol study when using pure materials and by-products of biodiesel fuel production, it is confirmed that ferment preparation Novozym 435 is less responsive to the admixtures present in raw materials. In fact, it is almost doubly-efficient when compared to Lipozyme RM IM. However, taking into account different prices of ferment preparations (Lipozyme RM IM is about 3 times cheaper than Novozym 435), it is possible to conclude that Lipozyme RM IM has future prospects in industrial synthesis. In order to achieve a higher output of esterification products, it is necessary to continue the research into the increased amounts of ferment preparation and perform the process in multiple steps.

\section{Conclusions}

In the process of free fatty acid esterification with methanol and glycerol, the highest efficiency was demonstrated by Novozym 435 and Lipozyme RM IM ferments. The process of free fatty acid esterification with methanol using 7\% Lipozyme RM IM (in relation to the amount of free fatty acid) should be performed in three steps, with methanol gradually added into the reaction media at 0.5 mole per one mole of oleic acid, as the ferment is inactivated by surplus methanol. Under these conditions, in 4 hours of the multi-step process, it is possible to esterify up to $60 \%$ of free fatty acids. This result is in contrast to a single-step process, which results only in $12 \%$ of esterification. Ferment preparation Novozym 435 is not inactivated by methanol; therefore, esterification with methanol of free fatty acids can be performed in one step, with the ratio of methanol and free fatty acids in the reaction media being 1.5:1. When using $3 \%$ of this ferment preparation, the reaction yields $78 \%$ of free fatty acids after 4 hours of the process. Free fatty acid esterification with glycerol is slowed by admixtures present in by-products of biodiesel fuel production. After 7 hours of reaction, only $82.2 \%$ of free fatty acids react using Novozym 435, and only $41.7 \%$ do in a case of Lipozyme RM IM, whereas in the case of esterification of pure oleic acid with pure glycerol, the amounts are $97.7 \%$ and $84.8 \%$, respectively. The efficiency of ferment preparation Novozym 435 compared to Lipozyme RM IM. is almost twice higher. However, taking into account the prices of ferment preparations, it is possible to conclude that Lipozyme RM IM has more prospects in the future industrial synthesis.

\section{Acknowledgement}

This research was carried out under the National Industrial Biotechnology Development Programme for 2007-2010. The authors sincerely appreciate the assistance of the Lithuanian State Science and Studies Foundation.

\section{References}

AKOH, C.C., CHANG, S.W, LEE G.C., SHAW J.F. Enzymatic approach to biodiesel production. J Agric Food Chem, 2007, Vol. 55, pp. 8995-9005.

DENG, L., TAN, T., WANG, F., XU, X. Enzymatic production of fatty acid alkyl esters with a lipase preparation from Candida $s p$. 99-125. Eur J Lipid Sci Technol, 2003, Vol. 105, pp. 727-734.

ERGAN, F., TRANI, M., ANDRE, G. Production of glycerides from glycerol and fatty acid by immobilized lipases in aqueous media. Biotechnol Bioeng, 2004, Vol. 35, No 2, pp. 195-200.

GODDARD, R., BOSLEY, J., AL-DURI, B. Lipasecatalysed esterification of oleic acid and thanol in a continuous packed bed reactor, using supercritical $\mathrm{CO}_{2}$ as solvent: approximation of system kinetics. J Chem Technol Biotechnol, 2000, Vol. 75, pp. 715-721.

GUMBYTĖ, M., MAKAREVIČIENĖ, V. Selectivity of lipases as biocatalyst in the glycerolysis of oleic acid and glycerol. Vagos (Research papers), 2007, Vol. 77, No. 30, pp. 90-95 (in Lithuanian).

KOWALSKI, B., TARANOWSKA, K., GRUCZYNSKA, E., BEKAS, W. Chemical and enzymatic interesterification of beef tallow and rapeseed oil blend with low content of tallow. J Oleo Sci, 2004, Vol. 53, No. 10, pp. 479-488.

KUMARI, A., MAHAPATRA, P., V. GARLAPATI, K., BANJEREE, R. Enzymatic transesterification of Jatropha oil. Biotechnol Biofuels, 2009, Vol. 2, No 1, pp. 17.

MAKAREVIČIENĖ, V., GUMBYTÉ, M. Esterification of free fatty acids with methanol using biotechnological methods. Agricultural engineering (Research papers), 2008, Vol. 40, No. 1, pp. 78-90 (in Lithuanian).

MAT RADZI, S., BASRI, M., BAKAR SALLEH, A., ARIFF, A, MOHAMMAD, R., ABDUL RAHMAN, B., RAJA ABDUL RAHMAN, R.N.Z. High performance enzymatic synthesis of oleyl oleate using immobilized lipase from Candida antartica. Electron J Biotechnol, 2005, Vol. 8, No. 3, pp. 292-298.

MONTRIMATE், K., STANIŠKIS, J., LAPINSKIENE, A.M. Potential of Greenhouse Gas Reduction Producing and Using Biodiesel from Fatty Waste. Environmental Research, Engineering and Management, 2010, Vol. 4, No. 54, pp. 34-42.

ROYON, D., DAZ, M., ELLENDER, G., LOCATELLI, S. Enzymatic production of biodiesel from cotton seed oil using $t$-butanol as a solvent. Bioresour Technol, 2007, Vol. 98, No. 3, pp. 648-653.

TRIPHATI, V., TRIVEDI, R., SINGH, R.P. Lipasecatalyzed synthesis of diacylglycerol and monoacylglycerol 
from unsaturated fatty acid in organic solvent system. J Oleo Sci, 2006, Vol. 55, No. 2, pp. 65-69.

WARABI, Y., KUSDIANA, D., SAKA, S. Reactivity of triglycerides and fatty acids of rapeseed oil in supercritical alcohols. Bioresour Technol, 2004, Vol. 91, No. 3, pp. 283-287.

YANG, T., REBSDORF, M., ENGELRUD, U., XU, $\mathrm{X}$. Monoacylglycerol synthesis via enzymatic glycerolysis using a simple and efficient reaction system. J Food Lipids, 2005, Vol. 12, pp. 299-312.
Prof. Dr. Violeta Makarevičiene - head of the Laboratory Chemical and Biochemical Research for Environmental Technology, Institute of Environment, Lithuanian University of Agriculture.

Main research areas: Vegetable oil, biofuel, biolubricant production technology, quality, impact on environmental.

Address

Studentu str. 11,

LT-4324 Akademija

Kaunas Lithuania

Tel./fax.:

+370 37752292

E-mail: violeta.makareviciene@lzuu.lt
Dr. Milda Gumbytè - research fellow of the Laboratory Chemical and Biochemical Research for Environmental Technology, Institute of Environment, Lithuanian University of Agriculture.

Main research areas: Biofuel, biolubricant production technology, quality, impact on environmental.

Address

Studentu str. 11,

LT-4324 Akademija

Tel./fax.:

Kaunas, Lithuania

E-mail:

$+37037752292$

agrotech@1zuu.lt
Dr. Eglè Sendžikienè - research fellow of the Laboratory Chemical and Biochemical Research for Environmental Technology, Institute of Environment, Lithuanian University of Agriculture.

Main research areas: Biofuel production technology, quality, impact on environmental.

Address Studentu str. 11,

LT-4324 Akademija

Kaunas Lithuania

Tel./fax.: $\quad+37037752292$

E-mail: $\quad$ egle.sendzikiene@lzuu.lt

\title{
Biodyzelino gamybos šalutinių produktų esterinimas metanoliu ir gliceroliu naudojant biokatalizatorius
}

\author{
Milda Gumbytė, Violeta Makarevičienè, Eglè Sendžikienė
}

Aplinkos institutas, Lietuvos žemès ūkio universitetas, Lietuva

(gauta 2011 m. gegužés mèn.; atiduota spaudai 2011 m. birželio mèn.)

Gaminant biodyzeliną, susidaro tokie šalutiniai produktai, kaip glicerolis ir laisvosios riebalų rūgštys. Ištirtos biocheminių metodų taikymo perdirbant šiuos šalutinius produktus galimybès. Nustatyta, kad laisvujų riebalų rūgščių esterinimas metanoliu naudojant lipazę Lipozyme RM IM turi būti vykdomas stadijomis palaipsniui pridedant metanolị ị reakcijos terpę. Taikant šių stadijų procesą, per 4 valandas galima suesterinti iki 60 \% laisvujjų riebalų rūgščių. Lipazè Novozym 435 nèra inaktyvuojama metanoliu, todèl procesa galima vykdyti viena stadija. Esterinimo gliceroliu procesą lètina šalutiniuose produktuose esančios priemaišos. Per 7 val. suesterinama tik $82,2 \%$ laisvujų riebalų rūgščiu katalizatoriumi naudojant Novozym 435 ir tik $41,7 \%$ laisvujjų riebalų rūgščių katalizatoriumi naudojant Lipozyme RM IM. Esterinant analitiškai gryną oleino rūgštį, šios vertès siekia atitinkamai $97,7 \%$ ir $84,8 \%$. Fermentinis preparatas Novozym 435 yra beveik dvigubai aktyvesnis nei Lipozyme RM IM nagrinètuose šalutinių produktų esterinimo procesuose. Tačiau atsižvelgiant ị gerokai mažesnę kainą, galima teigti, kad Lipozyme RM IM yra perspektyvus pramoninèje sintezèje. 